Acta Sci. Pol. Technol. Aliment. 15(1) 2016, 57-63

pISSN 1644-0730

eISSN 1889-9594

DOI: $10.17306 / J . A F S .2016 .1 .6$

ORIGINAL PAPER

Received: 7.07.2015

Accepted: 20.11.2015

\title{
EFFECTS OF SOLVENTS AND EXTRACTION METHODS ON THE CONTENT AND ANTIRADICAL ACTIVITY OF POLYPHENOLS FROM FRUITS ACTINIDIA ARGUTA, CRATAEGUS MONOGYNA, GAULTHERIA PROCUMBENS AND SCHISANDRA CHINENSIS
}

\author{
Barbara Pliszka ${ }^{\bowtie}$, Grażyna Huszcza-Ciołkowska, Elwira Wierzbicka \\ Chair of Chemistry, University of Warmia and Mazury in Olsztyn \\ Plac Łódzki 4, 10-957 Olsztyn, Poland
}

\begin{abstract}
Background. In line with the current tendency towards the production of the so-called safe foods, the use of environmentally-friendly methods for the extraction of polyphenols from fruits has been sought. Citric acid is a good solvent in the preparation of phenolic compounds for the food and pharmaceutical industries because it is a natural antioxidant and is non-toxic for the environment. Furthermore, new sources of polyphenols from fruit of orchard plants that are less known in Poland have been looked for. The aim of this study was to assess the content and antiradical activity of polyphenolic compounds in fruit extracts, depending on the extraction method employed. In addition, the yield of extraction processes was assessed.

Material and methods. The experimental materials were fruits of the following plants: Actinidia arguta, Crataegus monogyna, Gaultheria procumbens, Schisandra chinensis. For the extraction, aqueous solutions of citric acid (CAE) and methanol (ME) were used. The following were determined in fruit extracts: the content of total phenols (TP) and anthocyanins (A), and antiradical activity (DPPH and ABTS).

Results. In general, the C. monogyna fruit extracts were distinguished by the highest TP and A content. The TP and A content was significantly higher in fruit extracts obtained with the CAE method than in the ones produced with the ME method. The highest mean A/TP ratio was determined for $S$. chinensis fruit extracts. The antiradical activity (DPPH and ABTS) in fruit extracts did not depend on an extraction method, but on fruit species. Overall, a higher yield of extraction processes was achieved for the CAE method than for the ME method. Conclusions. The present study indicates that the selected extraction methods are able to obtain polyphenolic extracts from fruits with a high antiradical activity and high yield. The use of citric acid in order to extract polyphenols from fruits may be an alternative to the conventional extraction method, while being eco-friendly and more effective than the latter.
\end{abstract}

Key words: ABTS, DPPH, extraction, fruits, polyphenols, solvents

\section{INTRODUCTION}

Fruits are a source of polyphenolic compounds characterized by antioxidant, anticarcinogenic and cardiologic properties (Kähkönen et al., 2001; Zheng and Wang, 2003). Nowadays, there is a tendency to search for new sources of these compounds in fruits of orchard plants which are less popular in Poland: kiwifruit (Actinidia sp.), gaultheria (Gaultheria sp.), hawthorn (Crataegus sp.) and Wuweizi (Schisandra

『barbara.pliszka@uwm.edu.pl, phone/fax +48 895234801 
Pliszka, B., Huszcza-Ciołkowska, G., Wierzbicka, E. (2016). Effects of solvents and extraction methods on the content and antiradical activity of polyphenols from fruits Actinidia arguta, Crataegus monogyna, Gaultheria procumbens and Schisandra chinensis. Acta Sci. Pol. Technol. Aliment., 15(1), 57-63. DOI: 10.17306/J.AFS.2016.1.6

chinensis). Although these fruits have been used in traditional medicine for many years, their health-promoting properties are still being investigated, and new extraction methods are being searched in order to use this fruits in a better way in the food and pharmaceutical industries. Noteworthy are certain biological and therapeutical properties of these fruits. Consumption of kiwifruits with possess antioxidant properties, is thought to protect against cardiovascular diseases and cancers (Rush et al., 2002; Zuo et al., 2012). Hawthorn species effectively reduce the level of blood cholesterol and the risk of cardiovascular diseases (Chang et al., 2005; Zhang et al., 2002). The essential oil of Gaultheria procumbens contains methyl salicylate, an aspirin-like compound. This oil is marketed for external treatment of neuralgia, malign, arthralgia and other pains (Ribnicky et al., 2003; Wei-Rui et al., 2013). Recent studies have shown that Schisandra chinensis is known for its various biological and therapeutic properties, e.g. antioxidant, hepatoprotective (Cheng et al., 2013), immunomodulatory, anticancer (Zhao et al., 2014), and sedative-hypnotic ones (Wei et al., 2014).

The extraction of polyphenols from plant materials is the first step in the use of bioelements for the preparation of nutraceuticals, food ingredients and pharmaceutical products. For the extraction of polyphenolic compounds by conventional methods, organic solvents e.g. methanol are most often used, frequently with different proportions of water. Although these solvents are harmful to human health and also to the environment, they are effective in the extraction of polyphenols from fruits. Presently, there is a tendency for applying ecological methods of extracting polyphenolic compounds from fruit in accordance with the current trend towards the production of safe foods (Pliszka et al., 2008; 2013). In recent years citric acid has been used in a few studies on polyphenolic extractions from plant materials (Mai, 2015; Pliszka et al., 2013; Tzima et al., 2014; Wissam et al., 2012). It is worth continuing the research using citric acid for the extraction, as this is a non-toxic and environmentally-friendly solvent. In addition, citric acid is a natural antioxidant frequently added to foodstuffs in order to protect them against oxidation (Gromovaya et al., 2002).

In the present study, citric acid and methanol were used as solvents in the extraction of polyphenolic compounds from the fruits of less known orchard plants. The aim of this study was to assess the content and antiradical activity of polyphenolic compounds in extracts from selected fruit species, depending on the extraction method employed. In addition, the yield of extraction processes was assessed.

\section{MATERIAL AND METHODS}

\section{Plant material}

The following fruits were used as the experimental material: Actinidia arguta, Crataegus monogyna, Gaultheria procumbens and Schisandra chinensis. The fruits were obtained from the Experimental Garden of the University of Warmia and Mazury in Olsztyn (Poland). Fruit samples of $10 \mathrm{~g}$ were weighed out and stored at $-18^{\circ} \mathrm{C}$ for further study.

\section{Extraction with citric acid (CAE method) and with $80 \%$ methanol (ME method)}

Fruit samples were defrosted for $2 \mathrm{~h}$ at room temperature and then grounded in a mortar.

In the CAE method the homogenized material was poured over with $50 \mathrm{~cm}^{3}$ of citric acid solution of 0.1 $\mathrm{mol} \cdot \mathrm{dm}^{-3}$ concentration. The samples were left in dark for $24 \mathrm{~h}$ at $2^{\circ} \mathrm{C}$. After that time, flasks containing samples were subject to a shaking water bath at $37^{\circ} \mathrm{C}$ for $15 \mathrm{~min}$.

In the ME method the homogenized material was poured over with $50 \mathrm{~cm}^{3}$ of solution $80 \%$ methanol by shaking samples in a shaker at room temperature for 30 min.

The samples were filtered through Whatman No. 1 filter paper to separate the solid phase from the extracts of both methods. New portions $\left(30\right.$ and $\left.20 \mathrm{~cm}^{3}\right)$ of the solvents (citric acid or methanol) were used for the re-shaking of samples. Extracts of the same fruit species were combined together in the final stage, respectively for the CAE and ME methods.

The extraction yield (\%) was calculated as a ratio of the weight of extract to the weight of a sample used for the extraction.

Polyphenolic compounds. The content of total phenols (TP) in fruit extracts was determined by the Folin-Ciocalteu method (Singleton et al., 1999). The absorbance was measured at $\lambda=765 \mathrm{~nm}$ on a Shimadzu UV-1800 spectrophotometer. The content of 
Pliszka, B., Huszcza-Ciołkowska, G., Wierzbicka, E. (2016). Effects of solvents and extraction methods on the content and antiradical activity of polyphenols from fruits Actinidia arguta, Crataegus monogyna, Gaultheria procumbens and Schisandra chinensis. Acta Sci. Pol. Technol. Aliment., 15(1), 57-63. DOI: 10.17306/J.AFS.2016.1.6

TP was calculated from a calibration curve. Gallic acid (mg GAE $100 \mathrm{~g}^{-1} \mathrm{FW}$ ) was used as the equivalent (FW - fresh weight). The content of anthocyanins (A) in fruit extracts was determined by the Giusti and Wrolstad method (2001). Quantitative determination of A was carried out by measuring the difference in extract absorbance in buffer solutions with $\mathrm{pH} 1$ and $\mathrm{pH} 4.5$ at $\lambda=525 \mathrm{~nm}$ and $\lambda=700 \mathrm{~nm}$ one a Shimadzu UV-1800 spectrophotometer. The content of A was expressed as cyanidin 3-glucoside equivalents (mg CGE· $100 \mathrm{~g}^{-1} \mathrm{FW}$ ). Moreover, the ratio of anthocyanins to total phenols in the tested extracts of fruits was calculated (A/TP ratio).

Antiradical activity. The antiradical activity (DPPH) was determined by the Yen and Hung method (2000) with slight modification. The concentration of extract was $0.8 \mathrm{mg} \cdot \mathrm{cm}^{-3}$. The mixture was left to stand at room temperature for $30 \mathrm{~min}$, in dark. Absorbance was measured after at $\lambda=517 \mathrm{~nm}$ using Shimadzu UV1800 spectrophotometer. The results were expressed as an inhibition percentage. Inhibition of free radical DPPH in percent (I\%) was calculated as follows:

$$
\mathrm{I} \%=\left[\left(\mathrm{A}_{\text {control }}-\mathrm{A}_{\text {sample }}\right) / \mathrm{A}_{\text {control }}\right] 100 \%
$$

The antiradical activity (ABTS) was determined by the Miller et al. (1993) with slight modification. The concentration of extract was $0.2 \mathrm{mg} \cdot \mathrm{cm}^{-3}$. The mixture was left to stand at $37^{\circ} \mathrm{C}$ in for $6 \mathrm{~min}$. The absorbance was measured at $\lambda=734 \mathrm{~nm}$ on a Shimadzu UV-Vis 1800 spectrophotometer. The results were expressed as inhibition [\%].

\section{Statistical analysis}

The results were verified in three replications. The data regarding the content of polyphenolic compounds, A/TP ratio, the antiradical activity of fruit extracts, and yield of extraction processes were submitted to statistical analysis of variance for two-factorial experiments (t-Student test) using the Statistica 8.0 PL (StatSoft Tulsa, the USA) software package $(p<0.05)$. The calculations included the correlation between the total content of phenols and the correlation between the content of anthocyanins in fruit extracts obtained through the two methods: CAE and ME $(p<0.05)$.

\section{RESULTS}

Results on the content of polyphenols in extracts from the analysed fruit species are comprised in Table 1. Statistical calculations have demonstrated that the total phenolic (TP) content was the highest in C. monogyna and the lowest in $A$. arguta extracts, irrespective of the extraction method applied. The highest content of anthocyanins was detected in C. monogyna (CAE method) and $S$. chinensis extracts (ME method). Regardless of the extraction method, the A content in G. procumbens extracts was the lowest. Extracts from

Table 1. Content of polyphenolic compounds in fruit extracts

\begin{tabular}{|c|c|c|c|c|c|c|}
\hline \multirow{3}{*}{ Fruit extracts } & \multicolumn{2}{|c|}{$\mathrm{TP}$} & \multicolumn{2}{|c|}{ A } & \multirow{2}{*}{\multicolumn{2}{|c|}{$\mathrm{A} / \mathrm{TP}$}} \\
\hline & \multicolumn{2}{|c|}{$\mathrm{mg} \mathrm{GAE} \cdot 100 \mathrm{~g}^{-1} \mathrm{FW}$} & \multicolumn{2}{|c|}{$\mathrm{mg}$ CGE $\cdot 100 \mathrm{~g}^{-1} \mathrm{FW}$} & & \\
\hline & CAE & $\mathrm{ME}$ & CAE & $\mathrm{ME}$ & CAE & $\mathrm{ME}$ \\
\hline Actinidia arguta & c $171.0^{\mathrm{A}} \pm 8.5$ & c $102.7^{\mathrm{B}} \pm 7.6$ & -* & - & - & - \\
\hline Crataegus monogyna & a $913.0^{\mathrm{A}} \pm 41.8$ & a $602.7^{\mathrm{B}} \pm 17.0$ & a $16.2^{\mathrm{A}} \pm 0.7$ & b $7.3^{\mathrm{B}} \pm 0.6$ & c $0.018^{\mathrm{A}} \pm 0.001$ & c $0.012^{\mathrm{B}} \pm 0.001$ \\
\hline Gaultheria procumbens & c $180.7^{\mathrm{A}} \pm 5.5$ & b $134.3^{\mathrm{B}} \pm 7.2$ & c $7.8^{\mathrm{A}} \pm 0.9$ & c $5.1^{\mathrm{B}} \pm 0.3$ & b $0.043^{\mathrm{A}} \pm 0.004$ & b $0.038^{\mathrm{B}} \pm 0.001$ \\
\hline Schisandra chinensis & b $247.0^{\mathrm{A}} \pm 7.0$ & b $128.3^{\mathrm{B}} \pm 5.5$ & b $14.1^{\mathrm{A}} \pm 1.7$ & a $9.5^{\text {B }} \pm 0.6$ & a $0.057^{\mathrm{B}} \pm 0.005$ & a $0.074^{\mathrm{A}} \pm 0.002$ \\
\hline
\end{tabular}

$\mathrm{TP}$ - total phenols. A - anthocyanins. GAE - equivalents of gallic acid. CGE - equivalents of cyanidin. FW - fresh weight. CAE citric acid extract. $\mathrm{ME}-$ methanol extract. Results are mean $\pm \mathrm{SD}$.

*Does not contain anthocyanins.

Data in the same row denoted by capital letters are significantly different $(p<0.05)$.

For each solvent, values in the same column denoted by small letters are significantly different $(p<0.05)$. 
Pliszka, B., Huszcza-Ciołkowska, G., Wierzbicka, E. (2016). Effects of solvents and extraction methods on the content and antiradical activity of polyphenols from fruits Actinidia arguta, Crataegus monogyna, Gaultheria procumbens and Schisandra chinensis. Acta Sci. Pol. Technol. Aliment., 15(1), 57-63. DOI: 10.17306/J.AFS.2016.1.6

a

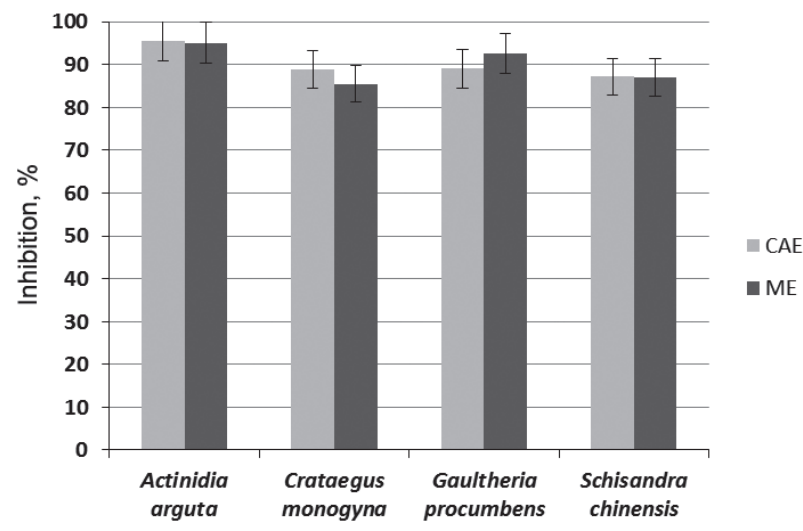

b

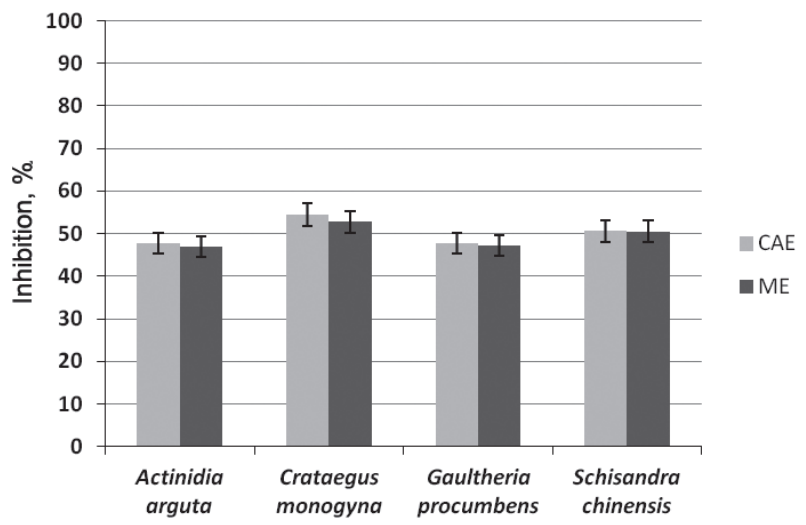

Fig. 1. Antioxidant activity of fruit extracts determined by: a - the DPPH method, $b$ - the ABTS method. CAE - citric acid extract. ME - methanol extract

A. arguta fruits did not contain any anthocyanins. The content of TP and A was significantly higher in fruit extracts produced with the CAE method than in the ones obtained with the ME method. The correlation between the TP content in extracts obtained with the CAE method and the TP content in extracts produced with the ME method was significant. The same correlation was observed between the A content in fruit extracts obtained with the CAE and the ME method. The correlation coefficients were $r=0.996$ and $r=0.720$ for TP and A, respectively. The calculations proved that the A/TP ratio was the highest in $S$. chinensis fruit extracts and the lowest in C. monogyna fruit extracts, irrespective of the extraction method. The A/TP ratio was significantly higher in C. monogyna and G. procumbens fruit extracts obtained with the CAE method than in the ones produced with the ME method. For the $S$. chinensis extracts, the above correlation was reverse. The current experiment revealed a significant interaction between the extraction methods and a fruit species in terms of TP and A as well as the A/TP ratio.

The antiradical activity of fruit extracts determined with the two methods (DPPH and ABTS) is illustrated in Figure 1. The antiradical activity of fruit extracts did not depend on an extraction method but on a fruit species. The DPPH assay demonstrated the highest antiradical activity was observed in extracts of A. arguta fruit, and the lowest by S. chinensis and
C. monogyna fruits. In turn, the ABTS assay showed the highest antiradical activity in $C$. monogyna fruit extracts and the lowest one in A. arguta and G. procumbens extracts.

The paper compares the yield of extraction processes applied to A. arguta, C. monogyna, G. procumbens and $S$. chinensis fruits according to two extraction methods: CAE and ME (Table 2). Statistical analysis of the experimental results has demonstrated that significantly higher yields were achieved with the CAE method, except for G. procumbens fruits, for which the extraction yields obtained with either of the methods did not differ significantly. Irrespective of the extraction method, the highest extraction yield was recorded for $S$. chinensis fruits.

Table 2. Yield of extraction from selected fruit species, $\%$

\begin{tabular}{lrc}
\hline \multirow{2}{*}{ Fruit extracts } & \multicolumn{2}{c}{ Method } \\
\cline { 2 - 3 } & \multicolumn{1}{c}{ CAE } & ME \\
\hline Actinidia arguta & $\mathrm{b} 86.32^{\mathrm{A}} \pm 0.98$ & c $60.94^{\mathrm{B}} \pm 1.89$ \\
Crataegus monogyna & $\mathrm{bc} 84.32^{\mathrm{A}} \pm 1.65$ & $\mathrm{~b} 80.49^{\mathrm{B}} \pm 1.41$ \\
Gaultheria procumbens & $\mathrm{b} 86.33^{\mathrm{A}} \pm 2.12$ & a $83.77^{\mathrm{A}} \pm 0.49$ \\
Schisandra chinensis & a $89.45^{\mathrm{A}} \pm 1.91$ & a $85.35^{\mathrm{B}} \pm 1.57$ \\
\hline
\end{tabular}

CAE - citric acid extract. ME - methanol extract. Results are mean \pm SD 
Pliszka, B., Huszcza-Ciołkowska, G., Wierzbicka, E. (2016). Effects of solvents and extraction methods on the content and antiradical activity of polyphenols from fruits Actinidia arguta, Crataegus monogyna, Gaultheria procumbens and Schisandra chinensis. Acta Sci. Pol. Technol. Aliment., 15(1), 57-63. DOI: 10.17306/J.AFS.2016.1.6

\section{DISCUSSION}

The results of the present study show that extracts from the C. monogyna fruits were generally distinguished by a high TP and A content, irrespective of the extraction method. Literature contains reports on the extraction of polyphenols from $A$. arguta and $S$. chinensis fruits by conventional methods using methanol, ethanol, and acetone. On the other hand, there is little information on polyphenols in C. monogyna and G. procumbens fruits. Currently, research is only carried out for other species of hawthorn and gaultheria. In different varieties of kiwifruit genotypes, the content of total phenols ranges from $41 \mathrm{mg}$ to $710 \mathrm{mg} / 100$ g FW (Du et al., 2009). According to Latocha et al. (2010), the content of total phenols in A. arguta was $79 \mathrm{mg} / 100 \mathrm{~g} \mathrm{FW}$. Wang (2013) reported that the content of TP in the fruits of $A$. arguta was $214.8 \mathrm{mg} / 100$ g, whereas Zuo et al. (2012) claimed that value to be higher. Wu et al. (2011) noted that the content of total phenols in S. chinensis fruits was $184.7 \mathrm{mg} / 100 \mathrm{~g}$, and the content of anthocyanins was $17.9 \mathrm{mg} / 100 \mathrm{~g}$ of fresh weight. The results obtained in the present study were similar to those provided by $\mathrm{Wu}$ et al. (2011). Pliszka et al. (2009), who performed extraction using citric acid, concluded that the content of total phenols in G. procumbens fruits ranged from $180.0 \mathrm{mg}$ to $495.2 \mathrm{mg} / 100 \mathrm{~g}$ of fresh matter, and the content of anthocyanins varied from $7.83 \mathrm{mg}$ to $13.11 \mathrm{mg} / 100 \mathrm{~g}$ of fresh matter, depending on the date of fruit harvest. The results obtained in the present study for G. procumbens (the CAE method) were in the same range as presented by Pliszka et al. (2009).

The fruit extracts obtained using the CAE method were richer in polyphenols than the extracts obtained with the ME method. The correlation coefficients indicate that two methods could be used alternately. The results of this study indicated a significant interaction between the extraction methods and the fruit species for both total phenols and anthocyanins, which supports previous studies (Pliszka et al., 2008). Kalt et al. (2001) claimed otherwise; when testing fruit extracts, they found no interaction between the extraction method and the fruit species for either total phenols or anthocyanins.

The A/TP ratio is the ratio of the content of anthocyanins (A) to the content of total phenols (TP) in the fruits, and according to Borowska and Mazur (2008), it is typical of specific species and varieties of fruit. This study shows the $\mathrm{A} / \mathrm{TP}$ ratio value was the highest for $S$. chinensis, since the share of anthocyanins in the total content of phenols was large. In extracts from the fruits analyzed here, the A/TP ratio was much lower than in fruits of black chokeberry or bilberry which are rich in red anthocyanin pigments (Pliszka et al., 2013).

The antiradical activity DPPH of the extracts from the fruits analyzed was dependent on the fruit species, and could be ranked in the following order: A. arguta $>$ G. procumbens $>C$. monogyna $=S$. chinensis. In the ABTS assay, the sequence appeared as follows: $C$. monogyna $>S$. chinensis $>A$. arguta $=G$. procumbens. The antioxidant properties of fruit extracts are increasingly more intensive as the concentration of polyphenolic compounds increases, albeit only up to a certain point, which depends on both a given antioxidant and an assay applied for testing (Marinova and Yanishlieva, 1997; Pliszka et al., 2005). On the other hand, no significant difference was found between the antiradical activity of the fruit extracts obtained with the two methods. In the available literature, the antiradical activity assayed according to the DPPH and ABTS protocol was usually determined in fruit extract obtained with traditional methods. Choi et al. (2012) reported that the antiradical activity for $S$. chinensis tested with DPPH and ABTS assays ranged from $78.36 \%$ to $83.62 \%$ and from $37.97 \%$ to $42.28 \%$, respectively. $\mathrm{Wu}$ et al. (2011) reported that antiradical activity (DPPH) in fruits of S. chinensis was $85.2 \%$. There are also reports implicating that a DPPH-assayed antiradical activity was high for extracts from fruits of Actinidia sp. (Du et al., 2009; Zuo et al., 2012), and Crataegus sp. (Rabiei et al., 2012). The results obtained in present study for the antiradical activity of the $G$. procumbens extracts (CAE method) were similar to those obtained by Pliszka et al. (2009), who also used citric acid for extraction.

This study compared the yield of the extraction processes applied to the tested fruit received according to the CAE and ME methods. The yield of the extraction processes depended mainly on the method used, and not on the species of fruit. Higher yields were obtained with the CAE than the ME method, except G. procumbens, where the yields achieved with two methods were not significantly different. 
Pliszka, B., Huszcza-Ciołkowska, G., Wierzbicka, E. (2016). Effects of solvents and extraction methods on the content and antiradical activity of polyphenols from fruits Actinidia arguta, Crataegus monogyna, Gaultheria procumbens and Schisandra chinensis. Acta Sci. Pol. Technol. Aliment., 15(1), 57-63. DOI: 10.17306/J.AFS.2016.1.6

\section{CONCLUSIONS}

The present study indicates that the selected extraction methods are able to obtain polyphenolic extracts from fruits with a high antiradical activity and high yield. The use citric acid in order to extract polyphenols from fruits may be an alternative to conventional methods whilst being eco-friendly and more effective than the latter. Further research into the improvement of extraction methods with citric acid is necessary before they are implemented in the food and pharmaceutical industries.

\section{REFERENCES}

Borowska, E. J., Mazur, B. (2008). Zmiany wybranych składników i właściwości antyoksydacyjnych borówki brusznicy w procesie otrzymywania przecierów [Changes in the selected components and antioxidant properties of cowberry in the purée production process]. Bromat. Chem. Toksykol., 41, 3, 303-307 [in Polish].

Chang, W. T., Dao, J., Shao, Z. H. (2005). Hawthorn: Potential roles in cardiovascular disease. Am. J. Chin. Med., 33, 1, 1-10.

Cheng, N., Ren, N., Gao, H., Lei, X., Zheng, J., Cao, W. (2013). Antioxidant and hepatoprotective effects of Schisandra chinensis pollen extract on $\mathrm{CCl}_{4}$-induced acute liver damage in mice. Food Chem. Toxicol., 55, 234-240.

Choi, E. J., Kim, S. H., Shim, S. H., Chung, H. J., Bang, W-S., (2012). Antioxidative activity of the n-hexane fractions from Spatholobus suberectus (SS), Scutellsria barbata (SB), Psoralea corylifolia (PC), Curcuma zedoaria (CZ), Schisandra chinensis (SC), and Corydalis turtschaninovii (CT). Korean J. Food Sci. Techn., 44, 4, 493-497.

Du, G. R., Li, M. J., Ma, F. W., Liang, D. (2009). Antioxidant capacity and the relationship with polyphenol and Vitamin C in Actinidia fruits. Food Chem., 113, 557-562.

Giusti, M. M., Wrolstad, R. E. (2001). Characterization and measurement of anthocyanins by UV-visible spectroscopy. Unit F1.2. In E. Wrolstad, S. J. Schwartz (Eds), Current protocols in food analytical chemistry (F1.2.1F1.2.13). New York, NY: John Wiley.

Gromovaya, V. F., Shapoval, G. S., Mironyuk, I. E. (2002). Antiradical and antioxidant activity of biologically active carboxylic acids. Russ. J. Gen. Chem., 72, 5, 774-777.
Kalt, W., Ryan, D. A., Duy, J. C., Prior, R. L., Ehlenfeldt, M. K., Vander Kloet, S. P. (2001). Interspecific variation in anthocyanins, phenolics, and antioxidant capacity among genotypes of highbush and lowbush blueberries (Vaccinium section cyanococcus spp.). J. Agric. Food Chem., 49, 10, 4761-4767.

Kähkönen, M. P., Hopia, A. I., Heinonen, M. (2001). Berry phenolics and their antioxidant activity. J. Agric. Food Chem., 49, 8, 4076-4082.

Latocha, P., Krupa, T., Wołosiak, R., Worobiej, E., Wilczak, J. (2010). Antioxidant activity and chemical difference in fruit of different Actinidia sp. Int. J. Food Sci. Nutr., 61, 4, 381-394.

Mai, D. S. (2015). Study on the extraction of polyphenol from Artocarpus altilis with ultrasonic wave technology optimized by central composite design-response surface method. J. Food Nutr. Sci., 3, 1-2, 115-118.

Marinova, E. M., Yanishlieva, N. V. (1997). Antioxidative activity of extracts from selected species of the family Lamiaceae in sunflower oil. Food Chem., 58, 3, 245-248.

Miller, N. J., Rice-Evans, C., Davies M. J., Gopinathan, V., Milner, A. (1993). A novel method for measuring antioxidant capacity and its application to monitoring the antioxidant status in premature neonates. Clin. Sci., 84, 4, 407-412.

Pliszka, B., Huszcza-Ciołkowska, G., Januszewicz, E., Warmińska-Radyko, I. (2013). Stability, microbiological quality, and antioxidant properties of extracts from berry fruits. Acta Alim., 42, 2, 256-263.

Pliszka, B., Huszcza-Ciołkowska, G., Wierzbicka, E. (2008). Effects of extraction conditions on the content of anthocyanins and bioelements in berry fruit extracts. Commun. Soil Sci. Plant Anal., 39, 5\&6, 753-762.

Pliszka, B., Waźbińska, J., Huszcza-Ciołkowska, G. (2009). Polyphenolic compounds and bioelements in fruits of eastern teaberry (Gaultheria procumbens L.) harvested in different fruit maturity phases. J. Elementol., 14, 2, 341-348.

Pliszka, B., Waźbińska, J., Puczel, U., Huszcza-Ciołkowska, G. (2005). Biologicznie czynne związki polifenolowe zawarte w owocach różnych odmian hodowlanych i dziko rosnących ekosystemów bzu czarnego [Biologically active polyphenolic compounds in elderberries of different cultivated varieties and wild-growing forms]. Zesz. Probl. Post. Nauk Roln., 507, 2, 443-449 [in Polish].

Rabiei, Kh., Bekhradnia, S., Nabavi, S. M., Nabavi, S. F., Ebrahimzadeh, M. A. (2012). Short Communication. Antioxidant activity of polyphenol and ultrasonic 
Pliszka, B., Huszcza-Ciołkowska, G., Wierzbicka, E. (2016). Effects of solvents and extraction methods on the content and antiradical activity of polyphenols from fruits Actinidia arguta, Crataegus monogyna, Gaultheria procumbens and Schisandra chinensis. Acta Sci. Pol. Technol. Aliment., 15(1), 57-63. DOI: 10.17306/J.AFS.2016.1.6

extracts from fruits of Crataegus pentagyna subsp. elburensis. Nat. Prod. Res., 26, 24, 2353-2357.

Ribnicky, D. M., Poulev, A., Raskin, I. (2003). The determination of salicylates in Gaultheria procumbens for use as a natural aspirin alternative. J. Nut. Funct. Med. Foods, 4, 1, 39-52.

Rush, E. C., Patel, M., Plank, L. D., Ferguson, L. R. (2002). Kiwifruit promotes laxation in the elderly. Asia-Pac. J. Clin. Nutr., 11, 2, 164-168.

Singleton, V. L., Orthofer, R., Lamuela-Raventós, R. M. (1999). Analysis of total phenols and other oxidation substrates and antioxidants by means of Folin-Ciocalteu reagent. Methods Enzymol., 299, 152-178.

Tzima, K., Kallithraka, S., Kotseridis, Y., Makris, D. P. (2014). Kinetic modelling for flavanol extraction from red grape (Vitis vinifera L.) pomace using aqueous organic acid solutions. Int. Food Res. J., 21, 5, 1919-1924.

Wang, Z. (2013). Extraction process of polyphenols form wild Actinidia arguta in Dandong. J. Eas. Liaoning Univ. (Nat. Sci.), 1, 8-11.

Wei, B., Li, Q., Fan, R., Su, D., Chen, X., Jia, Y., Bi, K. (2014). Determination of monoamine and amino acid neurotransmitters and their metabolites in rat brain samples by UFLC-MS/MS for the study of the sedative-hypnotic effects observed during treatment with $S$. chinensis. J. Pharm. Biomed. Anal., 88, 416-422.

Wei-Rui, L., Wen-Lin, Q., Zi-Zhen, L., Xiao-Hong, W., Rui, J., Shu-Yi, L., ..., Gai-Mei, S. (2013). Gaultheria: Phytochemical and Pharmacological Characteristics. Molecules, 18, 12071-12108.
Wissam, Z., Ghada, B., Wassim, A., Warid, K. (2012). Effective extraction of polyphenols and proanthocyanidins from pomegranate's peel. Int. J. Pharm. Pharm. Sci. 4, 3, 675-682.

Wu, X., Yu, H., Jing, H. (2011). Optimization of phenolic antioxidant extraction from Wuwuezi (Schisandra chinensis) pulp using Random-Centroid Optimization methodology. Int. J. Mol. Sci., 12, 9, 6255-6266.

Yen, G. C., Hung, C. Y. (2000). Effects of alkaline and heat treatment on antioxidative activity and total phenolics of extracts from Hsian-tsao (Mesona procumbens Hemsl.). Food Res. Int., 33, 487-492.

Zhang, Z. S., Ho, W. K. K., Huang, Y., Chen, Z. Y. (2002). Hypocholesterolemic activity of hawthorn fruit is mediated by regulation of cholesterol- $7 \alpha$-hydroxylase and acyl CoA: cholesterol acyltransferase. Food Res. Int., 35, 885-891.

Zhao, T., Feng, Y., Li, J., Mao, R., Zou, Y., Feng, W., ... Wu, X. (2014). Schisandra polysaccharide evokes immunomodulatory activity through TLR 4-mediated activation of macrophages. Int. J. Biol. Macromol., 65, 33-40.

Zheng, W., Wang, S. Y. (2003). Oxygen radical absorbing capacity of phenolics in blueberries, cranberries, chokeberries, and lingonberries. J. Agric. Food Chem., 51, 502-509.

Zuo, L. L., Wang, Z. Y., Fan, Z. L., Tian, S. Q., Liu, J. R. (2012). Evaluation of antioxidant and antiproliferative properties of three Actinidia (Actinidia kolomikta, Actinidia arguta, Actinidia chinensis) extracts in vitro. Int. J. Mol. Sci., 13, 5, 5506-5518. 